\title{
SOLVING CONVEX AND NON-CONVEX STATIC AND DYNAMIC ECONOMIC DISPATCH PROBLEMS USING HYBRID PARTICLE MULTI-SWARM OPTIMIZATION
}

\author{
Aamir Nawaz, Ehtasham Mustafa, Nasir Saleem, Muhammad Irfan Khattak, \\ Muhammad Shafi, Abdul Malik
}

Original scientific pape Economic Load Dispatch problem has been previously solved successfully with swarm techniques. However, power systems with complex behaviours still await a robust algorithm to be developed for their optimization more precisely. Economic Dispatch problem with constraints such as generator limits, total power demand, ramp rate limits and prohibited operating zones, makes the problem more complicated to solve even for global techniques. To overcome these complications, a new algorithm is proposed called Hybrid Particle Multi-Swarm Optimization (HPMSO). The proposed algorithm has a property of deep search with quite fast response. Convex and Non-convex cost functions along with equality and inequality constraints have been used to evaluate performance of proposed approach. Moreover, Dynamic Economic Dispatch cases have also been included in statistical studies to test the proposed approach even in real time. Different case studies have been accomplished using standard test systems of Static and Dynamic Economic Dispatch. Comparison of proposed approach and previous techniques show that the proposed algorithm has a better performance.

Keywords: convex and non-convex problems; economic dispatch; Hybrid Multi-Particle Swarm Optimization (HPMSO); valve-point effects

\section{Rješavanje konveksnih i ne-konveksnih statičkih i dinamičkih problema ekonomične otpreme primjenom više rojne optimizacije}

Izvorni znastveni članak Problem ekonomične otpreme opterećenja ranije se uspješno rješavalo tehnikama rojeva. Međutim, elektroenergetski sustavi složenog ponašanja još uvijek čekaju razvoj robustnog algoritma za njihovu precizniju optimizaciju. Problem ekonomične otpreme uz ograničenja kao što su ograničenja generiranja, ukupna potražnja energije, ograničenja brzine pristupa i zabranjene operativne zone, čini problem složenijim za rješavanje čak i globalnim tehnikama. Za prevladavanje tih komplikacija, predlaže se novi algoritam pod nazivom Hybrid Particle Multi-Swarm Optimization (HPMSO). Predložen algoritam ima svojstvo dubokog pretraživanja s prilično brzim odzivom. Vrednovanje učinkovitosti predloženog pristupa ispitivalo se konveksnim i nekonveksnim funkcijama troškova uz ograničenja jednakosti i nejednakosti. Štoviše, slučajevi dinamičke ekonomične otpreme također su bili uključeni u statistička istraživanja za testiranje predloženog pristupa čak i u stvarnom vremenu. Različite studije slučaja provedene su korištenjem standardnih sustava za ispitivanje statičke i dinamičke otpreme. Usporedba predloženog pristupa i prethodnih tehnika pokazala je da se predloženim algoritmom postižu bolji rezultati.

Ključne riječi: ekonomična otprema; Hybrid Multi-Particle Swarm Optimization; konveksni i ne-konveksni problemi; valve-point učinci

\section{Introduction}

Economic Load Dispatch (ELD) problem is a classical form of optimization problems and has been one of the most important decision-making processes in the operation of electrical power systems. The total systemwide generation cost is generally defined as the objective function of ELD problem. The equality and inequality power system constraints are embedded in ELD formulation, such as power balance and generation limits of each generating unit's output capacity. ELD problem has been thought of as a mathematically complex and highly nonlinear optimization problem, especially in larger systems. For many decades, many algorithms have been presented to solve the optimization problem of ELD. First, conventional deterministic approaches which resort to mathematical gradient information have been developed to obtain the minimum cost of ELD problem. To overcome the limitations of those deterministic algorithms in real system applications which are basically associated with the simplification of mathematical formulation, a variety of evolutionary frameworks that employ meta-heuristic computational intelligence have explored their capabilities to search optimal solution of ELD problem.

Non-convexity in real generating systems is due to valve point effects. Moreover, generating system's constraints such as prohibited operating zones and ramp rate limits increases the complexity of the ELD problems. In previous years, as an alternative to the conventional mathematical approaches, different heuristic methods have been implemented on ELD problem such as Differential Evolution [1], Evolutionary Programming [2], Genetic Algorithm [3, 4], Firefly Algorithm [5, 6], Harmony Search Algorithm [6, 7], Artificial Bee Colony [8], Bacterial Foraging Optimization [5, 9, 10], Simulated Annealing [6, 11] and Particle Swarm Optimization [8, 11-13] etc.

Rania in [4], has compared Particle Swarm Optimization (PSO) with Genetic Algorithm (GA). Both PSO and GA are tested on different benchmark test problems and space system design problems to show their effectiveness. Results show that PSO has greater computational efficiency than GA. In [14], Jinho proposed a memetic algorithm scheme in which he combined meta-heuristic algorithm and gradient based technique in order to find better solutions of Economic Dispatch (ED) problem involving valve point loading effect. The strengths of meta-heuristic algorithms in global optimization and gradient based methods in local optimization have been combined. Results are evident that this hybrid technique outperforms any other single approach in literature.

Karthikeyan [11] has proposed hybridize model of PSO with Simulated Annealing (SA) to solve economic dispatch problem. Updating the velocity of PSO and SA 
operator judgment are two major parameters of this hybrid algorithm. Results have been improved using this hybrid algorithm. Manoharan in [2], has proposed Evolutionary Programming with Leven-Marquardt optimization for solving multi area economic dispatch with multiple fuel options. Further, he has used test systems with multi-area and mutli-fuel options. Comparison of this proposed algorithm has been accomplished with Incremental Network Flow Programming and Spatial Dynamic Programming. Evaluation of algorithm has shown more optimal results than others in literature.

Augmented Langrangian Particle Swarm Optimization (ALPSO) has been proposed by Vinod in [13]. This algorithm has been tested on 3 units test system with different loads. Results have shown the proficiency of ALPSO over other algorithms. In [15], Kim has proposed Improved Mean Variance optimization with Kuhn-Tucker conditions and swap process (KMVO), for solving ED problems with valve point loading effects. Different non-convex ED problems have been tested on this algorithm such as with prohibited operating zones, multi-fuels options and transmission network losses.

Combined Economic and Emission Dispatch (CEED) problem has been solved using hybrid algorithm by Manteaw [8]. Hybrid algorithm includes Artificial Bee Colony (ABC) and PSO whose results are compared with previous algorithm in literature. CEED solution has been provided using Gravitational Search Algorithm (GSA) by Güvenç [16]. This algorithm has been applied on biobjective function to minimize economic and emission dispatch. Robustness and effectiveness of the proposed approach has been validated by applying it on different test systems.

Ashfaq in [17], has proposed a linear programming modified methodology for solving ELD problems. Comparison with other techniques in literature has shown proficiency of this algorithm. Lee has proposed an improved GA called Quantum Genetic Algorithm (QGA) in [3], for solving economic dispatch algorithm with tie line constraints and has also included the case of wind power generation. After comparing it with previous techniques, it has been proved to be the best among those algorithms.

Seeker Optimization Algorithm (SOA) has been proposed by Shaw in [18], for solving ED problems. SOA was inspired from human search capabilities. This algorithm has outperformed other techniques in literature, for solving non-convex constrained ED problems. Bisen in [19], has provided a comparative exploration of Quadratic Programming (QP) and General Algebraic Modelling System (GAMS) for solving ED problems. Robustness of proposed algorithm has been supported by experimental results of different test systems.

All these latest techniques performed well in optimizing ED problems but the proposed technique is aimed to outclass these techniques and can be used for more optimal generation of thermal units in power systems. The proposed hybrid technique has been prepared by Wang [20] for solving multi-modal complex optimization problems with constraints. In this paper, this technique has been utilized for solving complex ED problems with constraints.
This paper is organized as follows. Section 2 includes ED problem formulation with its constraints. Section 3 includes overview of PSO and Differential Algorithm (DE). Section 4 contains working philosophy of proposed hybrid technique. Section 5 includes results and discussion. Section 6 includes the conclusion of this research.

\section{Problem formulation \\ 2.1 Economic Dispatch with and without valve point loading}

Economic dispatch problem can be subdivided into two categories on the basis of fuel cost function. One is called Convex problem while the other is called NonConvex problem. In Convex problem, no valve point effects are considered and fuel cost function is quadratic function of generator coefficients as given in equation:

$$
F_{C}=\sum_{i=1}^{n g} \alpha_{i} P_{i}^{2}+\beta_{i} P_{i}+\gamma_{i}
$$

However, due to steam valve openings, nonconvexity appears in fuel cost function which is modelled in equation as given below:

$$
\begin{aligned}
& F_{C}=\sum_{i=1}^{n g} \alpha_{i} P_{i}^{2}+\beta_{i} P_{i}+\gamma_{i}+e_{i} \sin \left(f_{i}\left(P_{i}^{\min }-P_{i}\right)\right) \\
& P_{i}^{\min } \leq P_{i} \leq P_{i}^{\max }
\end{aligned}
$$

Furthermore, it is required to maintain power generation and demand at the same level. For this the following equality constraints must be satisfied.

$$
\begin{aligned}
& \sum_{i=1}^{n g} P_{i}=P_{D}+P_{L} \\
& P_{L}=\sum_{i=1}^{n g} \sum_{j=1}^{n g} P_{i} B_{i j} P_{i}+B_{i 0} P_{j}+B_{00}
\end{aligned}
$$

\subsection{Static and Dynamic Economic Dispatch}

In Static Economic Dispatch (SED), data of convex or non-convex test system for only particular hour has been taken. Therefore, this type of case study reveals results for particular demand for particular time. So, data of generator coefficients, transmission line coefficients, and total demand is required for evaluation of particular method for test systems.

In Dynamic Economic Dispatch (SED), data of convex or non-convex test systems are to be considered for 24 hours demand of systems. Therefore, data of generator coefficients, transmission line coefficients, total demand, ramp rate limits and prohibited operating zones, is required for systems statistical evaluation for particular technique.

Ramp rate limits are due to operational range of generator when load is increased or decreased. There operational possibilities are represented by inequalities constraints in Dynamic ED problem as given below: 
$P_{i}-P_{i}^{0} \leq U R_{i}$

where $U R_{i}$ represents upper ramp rate limit of generators when generation has to be increased due to increase in load and $P_{i}^{0}$ is previous generation of each generator.

$P_{i}^{0}-P_{i} \geq D R_{i}$

where $D R_{i}$ represents down ramp rate limit of generators when generation has to be decreased due to decrease in load and $P_{i}^{0}$ is previous generation of each generator.

Generalized expression for upper and down ramp rate limits for all generating units while not exceeding upper and lower limits of generator capacity limits, is given as:

$$
\begin{aligned}
& \max \left(P_{i}^{\min }, P_{i, t}^{0}-D R_{i}\right) \leq P_{i, t} \leq \min \left(P_{i}^{\max }, P_{i, t}^{0}+U R_{i}\right), \\
& i=1,2,3, \ldots, n g, t=1,2,3, \ldots, T
\end{aligned}
$$

where $P_{i, t}^{0}$ is previous hour generation of the $i^{\text {th }}$ generator and $P_{i, t}$ is present hour generation of the $i^{\text {th }}$ generator.

There can be one or more operating zones of generator where steam valves and auxiliary equipment generate vibrations, causing unstable and unreliable operation. These generation zones of generator are called Prohibited operating zones. These zones can be represented by inequality constraints of generating units as given below:

$$
\begin{aligned}
& P_{i, t}^{\min } \leq P_{i} \leq P_{i, 1}^{D} \\
& P_{i, r-1}^{U} \leq P_{i} \leq P_{i, r}^{D} \\
& P_{i, m}^{U} \leq P_{i} \leq P_{i, t}^{\max } \quad, r=2,3, \ldots, m
\end{aligned}
$$

All above mentioned constraints make DED problem more complex and difficult to optimize. In this paper, such problems are solved to evaluate performance of proposed algorithm.

\section{Overview of PSO and DE}

\subsection{Particle Swarm Optimization}

Particle Swarm Optimization is a global optimization algorithm which uses stochastic and population-based search approach for finding solution. In 1995, James Kennedy and Russel C. Eberhart [21] have described PSO algorithm. This algorithm is inspired by movements of flock of birds. Each bird is called a particle which is considered as potential solution. A certain problem called fitness function, is given to evaluate its solution. Main strength of PSO lies in communication network created between particles which share information of their region to find optimal solution. Each particle keeps track of its previous points through which it has passed. Furthermore, particle best of each particle is stored to avoid nonoptimal points.

Each particle has three $N$-dimensional vectors included which will be updated every time with position of particle. Here, $\mathrm{N}$ is dimension of search space while current position $\left(x_{j}\right)$, previous best solution $\left(p_{j}\right)$, and velocity of particle $\left(v_{j}\right)$ are three vectors evaluated for each particle.

At the $t^{\text {th }}$ generation, current position and velocity of the $i$ th particle can be represented as $x_{i}^{k}=\left(x_{i, 1}^{k}, x_{i, 2}^{k}, \ldots, x_{i, n}^{k}\right) \quad$ and $\quad v_{i}^{t}=\left(v_{i, 1}^{t}, v_{i, 2}^{t}, \cdots, v_{i, n}^{t}\right)$ respectively. However, best local position of each particle (pbest) and global best position of the whole swarm (gbest) can be represented as pbest $_{i}^{t}=\left(\right.$ pbest $_{i, 1}^{t}$, pbest $_{i, 2}^{t}, \cdots$, pbest $\left._{i, n}^{t}\right) \quad$ and gbest $^{t}=\left(\right.$ gbest $_{1}^{t}$, gbest $_{2}^{t}, \cdots$, gbest $\left._{n}^{t}\right)$ respectively.

In every generation, these vectors are updated by equations given below:

$$
\begin{aligned}
& v_{i, j}^{t+1}=w v_{i, j}^{t}+k r_{1}\left(\text { pbest }_{i}^{t}-x_{i, j}^{t}\right)+k r_{2}\left(\text { gbest }_{j}^{t}-x_{i, j}^{t}\right) \\
& x_{i, j}^{t+1}=x_{i, j}^{t}+v_{i, j}^{t+1}
\end{aligned}
$$

where $w$ represents weight for avoiding divergence, $j$ is representing $n$-dimensional vector, $k$ represents acceleration coefficient and $r_{1}$ and $r_{2}$ are random numbers in range $[0,1]$.

Wang in [20], has replaced velocity Eq. (10) with Eq. (12) because randomness in certain limit increases convergence of PSO. Equation is given below:

$$
v_{i, j}^{t}=\left|\operatorname{rand}_{1}\right|\left(\text { pbest }_{i, j}^{t}-x_{i, j}^{t}\right)+\mid \text { Rand }_{2} \mid\left(\text { gbest }_{j}^{t}-x_{i, j}^{t}\right)
$$

where $r a n d_{1}$ and $r a n d_{2}$ are positive random numbers.

\subsection{Differential Evolution}

Differential evolution is a population based stochastic evolutionary algorithm for global optimization. DE attractiveness lies in its simplicity and powerful features for numerical optimization. DE uses perturbing vectors as in Nelder Mead operators which makes it different from genetic algorithm. DE was proposed by Storn and Price [22] in 1995. There are three basic operators of DE which are crossover, selection and mutation.

DE initializes a population consisting of $\mathrm{Nn}$ dimensional vectors as given below:

$$
\vec{x}_{i}^{t}=\left\{x_{i, 1}^{t}, x_{i, 2}^{t}, \ldots, x_{i, n}^{t}\right\}, \quad i=1,2, \ldots, N
$$

where $t$ denotes generation of population and $\vec{x}_{i}$ is the target vector. Each of $N$ vectors undergoes three (3) different operations such as mutation, crossover and selection. There are different versions of DE but "DE/rand/1/bin" is considered the best of all versions.

In mutation operation, vectors are randomly selected for mutation. At the $t^{\text {th }}$ generation, three vectors $\overrightarrow{x_{r_{1}}}, \overrightarrow{x_{r_{3}}}$ and $\vec{x}_{r_{3}}$ are mutated to form a mutant vector $\vec{v}_{i}^{t}=\left\{v_{i, 1}^{t}, v_{i, 2}^{t}, \ldots, v_{i, n}^{t}\right\}$ by using the following equations: 


$$
\overrightarrow{v_{i}}=\vec{x}_{r_{1}}+F\left(\vec{x}_{r_{2}}-\vec{x}_{r_{3}}\right)
$$

where $F$ is a weighted difference function of two vectors.

In crossover operation, crossover vector $\vec{u}_{i}^{t}$ is formed by using binomial crossover operation on elements of target vector $\vec{x}_{i}^{t}$ and mutant vector $\vec{v}_{i}$ as given below:

$u_{i, j}^{t}= \begin{cases}v_{i, j}^{t}, & \text { if } \text { rand }_{j} \leq C_{r} \text { or } j=j_{\text {rand }} \\ x_{i, j}^{t}, & \text { otherwise, }\end{cases}$

where $i=1,2, \ldots, N, j=1,2, \ldots, n, j_{\text {rand }}$ and rand $_{j}$ are randomly chosen integers within range $[1, n]$ and the $j^{\text {th }}$ evaluation of uniform random generator and $C_{r} \in(0,1)$.

In selection procedure, objective function values of crossover vector $\vec{u}_{i}^{t}$ and target vector $\vec{x}_{i}^{t}$ are compared and optimal value is selected to be included in next generation.

$\vec{x}_{i}^{t+1}= \begin{cases}\vec{u}_{i}^{t}, & \text { if } f\left(\vec{u}_{i}^{t}\right) \leq f\left(\vec{x}_{i}^{t}\right), \\ \vec{x}_{i}, & \text { otherwise, }\end{cases}$

The process of mutation, crossover and selection continues until some stop criteria is reached. Furthermore, scaling factor $F$, population size $N$ and crossover constant
$C_{r}$ are three parameters used to control convergence of DE.

\section{Hybrid Technique HPMSO-DE}

This paper proposes a new hybrid technique called Hybrid Particle Multi-Swarm Optimization (HPMSO) for solving economic dispatch problem. In this hybrid technique, modified version of PSO is used along with differential evolution. The strategy of this hybrid approach lies in using multiple swarms to search for optimal solution. Two types of swarms have been taken into account; one is main swarm while the other is subswarm. Multiple Sub-swarm is produced by taking population of neighbours. Each sub-swarm has its local best and each particle has its personal best. Therefore, equations 11 and 12 can be written as:

$v_{i, j}^{t}=\mid$ rand $_{1} \mid\left(\right.$ pbest $\left._{i, j}^{t}-x_{i, j}^{t}\right)+\mid$ Rand $_{2} \mid\left(\right.$ lbest $\left._{j}^{t}-x_{i, j}^{t}\right)$

$x_{i, j}^{t+1}=x_{i, j}^{t}+v_{i, j}^{t+1}$

where lbest is local best of each sub-swarm.

In each generation of HPMSO, different procedures take place such as splitting of main swarm, evolution of sub-swarm and selection of personal best using DE.

Figure 1 shows general framework of HPMSO algorithm. Random swarm is initialized of $N$ particles and generation cost $f$ and constraint violation $G$ is calculated. Furthermore, swarm is partitioned and local bests in subswarms and personal bests of each particle are updated till termination criteria.

Algorithm: general framework of HPMSO

Step $1 t=0$;

Step 2 Initially generate random swarm $\mathrm{S}_{0}$ of $N$ particles each having generator values, i.e, $P_{1}^{t}, \ldots, P_{N}^{t}$

Step 3 For each particle, calculate generation cost $f\left(\vec{x}_{i}^{t}\right)$ and total generation constraint violation $G\left(\vec{x}_{i}^{t}\right)$

Step 4 For each particle, record personal best generation cost i.e., $\overrightarrow{\text { pbest }}_{i}^{t}, \ldots, \overrightarrow{p b e s t}_{N}^{t}$.

Step 5 while (termination criteria $=$ false) do

Step 6 split each swarm into sub-swarms and use Eqs. (17) and (18) for evolution of sub-swarms

Step 7 replace/update personal best (best generation cost) of each particle by new particles with optimal solutions using $\mathrm{DE}$

Step $8 t=t+1$;

Step 9 end while

Figure 1 General framework of HPMSO

Fig. 2 shows pseudo code for partitioning of swarm and evolution of sub-swarm. This algorithm initializes swarm and sorts the swarm according to generation cost of feasible solutions. Moreover, swarm is partitioned into sub-swarms. Local best of each sub-swarm and personal best of each particle is updated. First particle of each subswarm is selected as local best particle of sub-swarm. If other particles of sub-swarm are very close to local best, learning will not improve results significantly.

Further, all sub-swarms are evolved using Eqs. (17) and (18). All sub-swarms are built-up in different regions of search space and local best is the best particle of each sub-swarm, so every particle must follow trajectory towards local best. In this way, multiple local optima can be explored to develop diversity in swarm which will have a significant effect on finding global optima.
In the course of finding global optima, variable value $x_{i, j}^{t+1}$ can violate boundary constraints. To satisfy this constraint, the following equation will be used:

$x_{i, j}^{t+1}= \begin{cases}0.5\left(x_{i, j}^{t}+L_{j}\right) & \text { if } x_{i, j}^{t}<L_{j} \\ 0.5\left(x_{i, j}^{t}+U_{j}\right) & \text { if } x_{i, j}^{t}>U_{j}\end{cases}$

Fig. 3 shows the algorithm of updating personal best on the basis of generation cost and least constraint violation by Differential Evolution algorithm. DE is used for improving global search capability of multi-swarm. DE is applied to improve personal best $\overrightarrow{\text { Pbest }_{i}}$ of each particle. DE has used mutation operator to explore 
different regions of search space where swarm has not reach in evolution process. So, local best can be moved to such potential regions of search space where chance of global optima existence increases.

In $\mathrm{DE}$, crossover vector $u_{i, j}^{t}$ must satisfy boundary constraints. Therefore, the following equation is used to take care of boundary conditions:

$$
u_{i, j}^{t}= \begin{cases}L_{j}, & \text { if }(p \leq 0.5) \wedge\left(u_{i, j}^{t}<L_{j}\right) \\ U_{j}, & \text { if }(p \leq 0.5) \wedge\left(u_{i, j}^{t}>U_{j}\right) \\ 2 L_{j}-u_{i, j}^{t}, & \text { if }(p>0.5) \wedge\left(u_{i, j}^{t}<L_{j}\right) \\ 2 U_{j}-u_{i, j}^{t}, & \text { if }(p>0.5) \wedge\left(u_{i, j}^{t}>U_{j}\right)\end{cases}
$$

where $p$ is uniformly distributed number in range $[0,1]$.

\section{Algorithm for splitting of swarm and evolution of sub-swarm}

Input Arguments: $P=\left\{\overrightarrow{P_{1}}, \ldots, \overrightarrow{P_{N}}\right\}, P^{\prime}=\phi$, Pbest $=\left\{\overrightarrow{\text { pbest }_{1}}, \ldots, \overrightarrow{\text { pbest }_{N}}\right\}$, Pbest $^{\prime}=\phi$

Step $1 k=0$;

Step 2 sorting of swarm i)feasible and infeasible solutions are separated ii) On the basis of generation cost values, feasible solutions are sorted in ascending order iii) On the basis of degree of total generation constraint violation, infeasible solutions are sorted in ascending order

Step 3 while $k<\left(N / N_{s}\right)$ do

Step $4 \overrightarrow{S_{1}}=$ first particle in sub-swarm;

Step 5 find out $\left(N_{s}-1\right)$ particles with the largest Euclidean distance from $\overrightarrow{S_{1}}$ which are denoted as $\overrightarrow{S_{2}}, \ldots, \overrightarrow{S_{N s}}$

Step 6 let $M_{1}=\left\{\overrightarrow{S_{1}}, \ldots, \overrightarrow{S_{N s}}\right\}$ and personal bests of $S_{1}$ are represented as $\overrightarrow{\text { Sbest }}_{1}, \ldots, \overrightarrow{\text { Sbest }}_{N s}$, let

$$
M_{2}=\left\{{\overrightarrow{\text { Sbest }_{1}}}_{1} \ldots, \overrightarrow{\text { Sbest }}_{N s}\right\}
$$

Step $7 P=P \backslash M_{1}$ and Pbest $\backslash M_{2}$;

Step 8 For each particle of set $M_{1}$, update position of $\overrightarrow{S_{i}}$ and $\overrightarrow{v_{i}}$ as given below;

for $j=1: n$

$v_{i, j}=\mid$ rand $_{1} \mid\left(\right.$ Sbest $\left._{i, j}-S_{i, j}\right)+\mid$ rand $_{2} \mid\left(\right.$ lbest $\left._{i, j}-S_{i, j}\right)$;

$S_{i, \mathrm{j}}=S_{i, j}+v_{i, j}$;

end for

Step 9 Calculate generation cost $f\left(\overrightarrow{S_{i}}\right)$ and total generation constraint violation $G\left(\overrightarrow{S_{i}^{\prime}}\right)$ for $i=1,2, \ldots, N_{s}$. Compare $\overrightarrow{S_{i}}$ and $\overrightarrow{\text { Sbest }_{i}}$ and if $\overrightarrow{S_{i}}$ wins, then update $\overrightarrow{\text { Sbest }_{i}}$.

Step $10 P^{\prime}=P^{\prime} \cup M_{1}$ and Pbest $^{\prime}=$ Pbest $^{\prime} \cup M_{2}$;

Step $11 k=k+1$;

Step 12 end while

Step $13 P^{\prime}=P^{\prime} \cup P$ and Pbest $^{\prime}=$ Pbest $^{\prime} \cup$ Pbest;

Output: $P^{\prime}$ and Pbest ${ }^{\prime}$

Figure 2 Algorithm for partitioning and evolution of sub-swarm

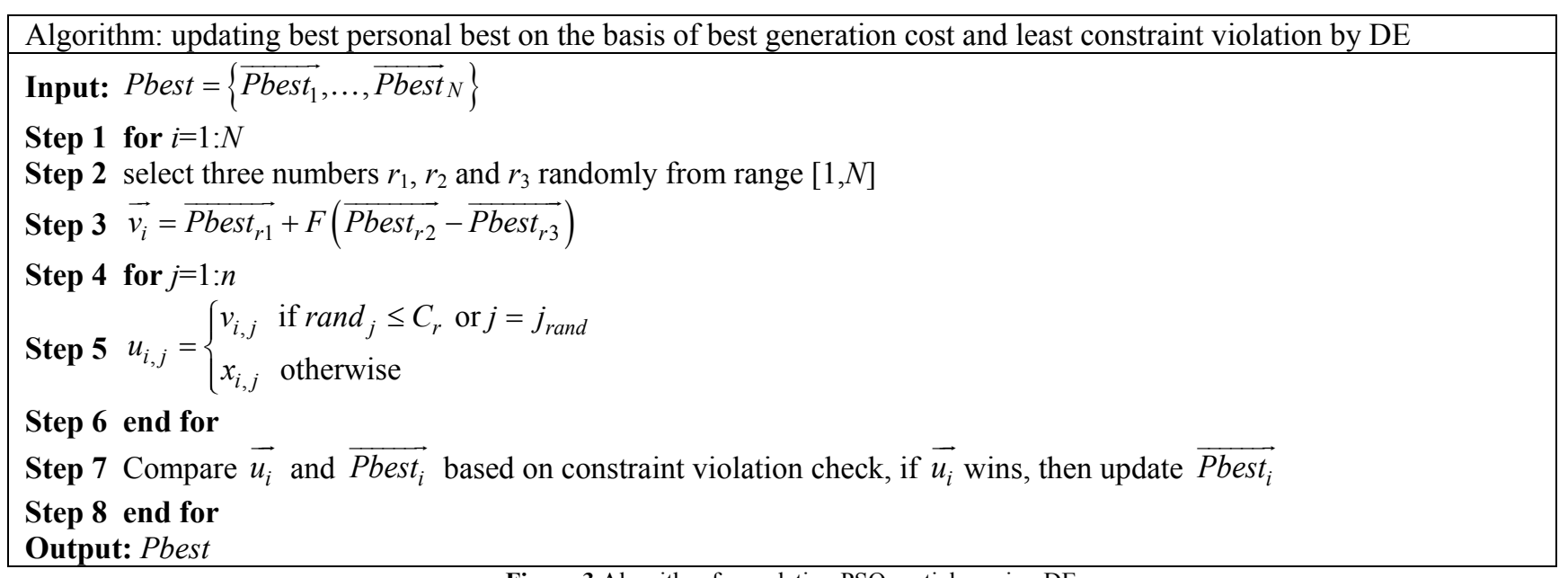

Figure 3 Algorithm for updating PSO particles using DE 


\section{Experimental analysis \\ 5.1 Test systems}

An extensive empirical study has been performed using different test systems for Static and Dynamic Economic Dispatch problems. Furthermore, test systems with and without valve point effects have been taken into account.

SED problems without valve point effects are 3Machine Test System with No Losses (3-MTSNL), 6Machine Test System with Losses (6-MTSL) and 20Machine Test System with Losses (20-MTSL) while with valve point effects are 3- Machine Test System with Losses (3-MTSL), 13- Machine Test System with No Losses (13-MTSNL) and 40- Machine Test System with No Losses (40-MTSNL).

DED problems without valve point effects are 3Machine Test System with No Losses (3-MTSNL) while with valve point effects are 5-Machine Test System with Losses (5-MTSL).

All these case studies have been carried out on platform of INTEL CORE i5, $2.50 \mathrm{GHz}, 4 \mathrm{~GB}$ memory while the proposed algorithm has been developed in MATLAB r2011a.

\subsection{Parameter setting}

In our case studies, all experiments have been run independently 50 times in MATLAB and each run is terminated if termination criteria are met or maximum number of generations has elapsed. Moreover, DE parameters are set to $F=0,7$ and $C_{\mathrm{r}}=1,0$. Also tolerance value for equality constraint $\varepsilon$ is set to 0,0001 . However, changing parameters with respect to different problems are given in Tab. 1.

Table 1 Parameter setting for different test systems

\begin{tabular}{|c|c|c|c|c|}
\hline \multirow{2}{*}{ Type of test systems } & \multirow{2}{*}{ Different Test Systems } & \multicolumn{3}{|c|}{ Changing Parameters } \\
\cline { 2 - 5 } & & Population size $N$ & Size of sub-swarm & Number of generations \\
\hline \hline \multirow{2}{*}{$\begin{array}{c}\text { SED without valve point } \\
\text { effects }\end{array}$} & 3-MTSNL & 5 & 2 & 200 \\
\cline { 2 - 5 } & 6-MTSL & 50 & 6 & 1000 \\
\hline \multirow{3}{*}{\begin{tabular}{c} 
SED with valve point effects \\
\cline { 2 - 5 }
\end{tabular}} & 20-MTSL & 50 & 8 & 2000 \\
\cline { 2 - 5 } & 3-MTSL & 50 & 6 & 2000 \\
\hline $\begin{array}{c}\text { DED without valve point } \\
\text { effects }\end{array}$ & 40-MTSNL & 60 & 8 & 3000 \\
\hline DED with valve point effects & 3-MTSNL & 30 & 8 & 100 \\
\hline
\end{tabular}

Table 2 SED using different techniques for various test systems

\begin{tabular}{|c|c|c|c|c|c|c|}
\hline \multirow{3}{*}{ Methods } & \multicolumn{6}{|c|}{ Power Generation cost (\$) } \\
\hline & \multicolumn{3}{|c|}{ Without Valve Point Effects } & \multicolumn{3}{|c|}{ With Valve Point Effects } \\
\hline & 3-MTSNL & 6-MTSL & 20-MTSL & 3-MTSL & 13-MTSNL & 40-MTSNL \\
\hline LIM & 8194,36 & - & 62456,64 & - & - & - \\
\hline MPSO & 8194,36 & - & - & 8234,07 & - & - \\
\hline GA & 8194,98 & - & - & 8237,60 & - & - \\
\hline IEP & 8194,36 & - & - & 8234,09 & - & - \\
\hline SWT & - & 18721,39 & - & - & - & - \\
\hline IMPSO & - & 18721,50 & & - & - & - \\
\hline Hopfield & - & - & 62456,63 & - & - & - \\
\hline SA & - & - & - & - & 17994,10 & - \\
\hline PS & - & - & - & - & 18030,70 & - \\
\hline SQP & - & - & - & - & 18098,30 & - \\
\hline SA-SQP & - & - & - & - & 17989,00 & - \\
\hline PS-SQP & - & - & - & - & 17974,50 & - \\
\hline BFA & - & - & - & - & - & 121423,63 \\
\hline PSO & - & - & - & - & - & 121735,47 \\
\hline MHS & - & - & - & - & - & 121415,45 \\
\hline HBMO & - & - & - & - & - & 121412,57 \\
\hline MHBMO & - & - & - & - & - & 121412,57 \\
\hline MFA & - & - & - & - & - & 121414,91 \\
\hline HMPSO & 8194,36 & 18529,31 & 62452,19 & 8234,07 & 17971,15 & 121406,05 \\
\hline
\end{tabular}

\subsection{Experimental results of Static Economic Dispatch (SED)}

In SED, different case studies have been carried out with and without valve point effects as given further.

\subsubsection{Without Valve Point Effects}

In the case of problems without valve point effects, 3 , 6 and 20 Machine Test Systems are evaluated by the proposed algorithm. For 3-MTSNL, data of generators' coefficient are taken from [12]. Furthermore, optimal solution of economic dispatch of proposed algorithm is compared with other algorithms in literature such as Lambda Iteration Method (LIM), Modified Particle Swarm Optimization (MPSO), GA, Improved Evolutionary Algorithm (IEP)[12].

In case of 6-MTSL, fuel cost coefficients of generating units and transmission line coefficients are taken from [10, 23]. Fuel cost calculated using the 
proposed hybrid algorithm has been compared with previous techniques such as Surrogate Worth Trade-off (SWT) and Improved Particle Swarm Optimization (IMPSO) [10, 23].

In 20-MTSL, data of generators' coefficients and transmission line coefficients have been taken from [6]. Proposed algorithm has been compared with LIM and Hopfield method [6].

\subsubsection{With Valve Point Effects}

In case of problems with valve point effects, 3, 13 and 40-Machine Testing Systems are tested with the proposed algorithm. In 3-MTSL, data of generator's coefficient and transmission line coefficients have been taken from [12]. Comparison of the proposed approach has been accomplished with previous techniques like GA, MPSO and Improved Evolutionary Programming (IEP).

For 13-MTSNL, data of generators' coefficients are taken from $[1,6]$. Proposed approach has been compared with other techniques in literature [1,6] like SA, Pattern Search method (PS), Sequential Quadratic Programming (SQP), SA-SQP and PS-SQP.

For 40-MTSNL, data of generator's coefficients have been taken from [14]. Furthermore, the proposed hybrid algorithm has been compared with algorithms such as PSO, Memetic Harmony Search algorithm (MHS), Honey Bee Mating Optimization (HBMO), Memetic Honey Bee Mating Optimization (MHBMO), and Memetic Firefly Algorithm (MFA) given in [14].

All above discussed results are tabulated in Tab. 2.

\subsection{Experimental Results of Dynamic Economic Dispatch (DED)}

DED is considered to be the most difficult problem to optimize as it predicts generation of each generator with lowest cost for next 24 hours. The following cases have been considered in this study.

\subsubsection{Without Valve Point Effects}

In this case study, 3-MTS without transmission losses have been considered. Data of generators' coefficients have been taken from [9]. Comparison of the proposed hybrid approach has been done with previous algorithms in literature [9] such as Bacterial Foraging Algorithm (BFA) and Improved Bacterial Foraging Algorithm (IBFA).

Table 3 Power generation cost or SED for different test systems

\begin{tabular}{|c|c|c|}
\cline { 2 - 3 } \multicolumn{1}{c|}{} & \multicolumn{2}{|c|}{ Power Generation cost (\$) } \\
\hline Methods & $\begin{array}{c}\text { Without Valve Point } \\
\text { Effects }\end{array}$ & $\begin{array}{c}\text { With Valve Point } \\
\text { Effects }\end{array}$ \\
\cline { 2 - 3 } & $3-$ MTSNL & 5-MTSL \\
\hline BFA & 104137,00 & - \\
\hline PSO & 103701,00 & - \\
\hline SA & - & 50124,00 \\
\hline MSL & - & 47356,00 \\
\hline HMPSO & 98656,01 & 49216,80 \\
\hline
\end{tabular}

\subsubsection{With Valve Point Effects}

In case study of 5-MTS with transmission losses, data of generators' coefficients and transmission line coefficients are taken from [9]. Proposed hybrid algorithm has been compared with PSO, SA, Maclaurin series based Lagrangian method (MSL) from literature [9].

Results show the proficiency of proposed hybrid algorithm as compared to other algorithms as shown in Tab. 3.

\section{Conclusion}

This paper has proposed a hybrid approach called Hybrid Particle Multi-Swarm Optimization (HPMSO) for solving convex and non-convex ED problems. PSO with multi-swarm search capability and DE for deep search in each swarm for the best particle, make this algorithm robust and unique in its working. Furthermore, both SED and DED cases have been solved with the proposed algorithm. HPMSO is capable of handling constraints and complex optimization problems. Experimental results of different test systems prove effectiveness of the proposed algorithm as compared to other techniques in literature. In the future, this algorithm can be further applied to other optimization problems to validate its efficiency.

\section{References}

[1] Coelho, L. D. S.; Mariani, V. C. Combining of chaotic differential evolution and quadratic programming for economic dispatch optimization with valve-point effect. // Power Systems, IEEE Transactions on. 21, (2006), pp. 989996. https://doi.org/10.1109/TPWRS.2006.873410

[2] Manoharan, P.; Kannan, P.; Ramanathan, V. A Novel EP approach for Multi-area economic dispatch with multiple fuel options. // Turk. Journal of Elect. Engineering. 16, (2008), pp. 1-20.

[3] Lee, J.-C.; Lin, W.-M.; Liao, G.-C.; Tsao, T.-P. Quantum genetic algorithm for dynamic economic dispatch with valve-point effects and including wind power system. // International Journal of Electrical Power \& Energy Systems. 33, (2011), pp. 189-197. https://doi.org/10.1016/j.jijepes.2010.08.014

[4] Hassan, R.; Cohanim, B.; De Weck, O.; Venter, G. A comparison of particle swarm optimization and the genetic algorithm. // Proceedings of the 1st AIAA multidisciplinary design optimization specialist conference, 2005, pp. 1-13. https://doi.org/10.2514/6.2005-1897

[5] Yang, X.-S.; Hosseini, S. S. S.; Gandomi, A. H. Firefly algorithm for solving non-convex economic dispatch problems with valve loading effect. // Applied Soft Computing. 12, (2012), pp. 1180-1186. https://doi.org/10.1016/j.asoc.2011.09.017

[6] Ahmed, I.; Rao, A. R.; Shah, A.; Alamzeb, E.; Khan, J. A. Performance of Various Metaheuristic Techniques for Economic Dispatch Problem with Valve Point Loading Effects and Multiple Fueling Options. // Advances in Electrical Engineering. Vol. 2014, (2014).

[7] Khorram, E.; Jaberipour, M. Harmony search algorithm for solving combined heat and power economic dispatch problems. // Energy Conversion and Management. 52, (2011), pp. 1550-1554. https://doi.org/10.1016/j.enconman.2010.10.017

[8] Manteaw, E. D.; Odero, N. A. Combined Economic and Emission Dispatch solution using ABC_PSO Hybrid algorithm with valve point loading effect. // International 
Journal of Scientific and Research Publications. 2, (2012), pp. 1-9.

[9] Pandit, N.; Tripathi, A.; Tapaswi, S.; Pandit, M. An improved bacterial foraging algorithm for combined static/dynamic environmental economic dispatch. // Applied Soft Computing. 12, (2012), pp. 3500-3513. https://doi.org/10.1016/j.asoc.2012.06.011

[10] Farajianpour, S.; Mohammadi, A.; Tavakoli, S.; Barakati, S. M. Improved Bacterial Foraging Algorithm for Optimum Economic Emission Dispatch with Wind Power. // TELKOMNIKA (Telecommunication Computing Electronics and Control). 10, (2012), pp. 675-682. https://doi.org/10.12928/telkomnika.v10i4.855

[11] Karthikeyan, V.; Senthilkumar, S.; Vijayalakshmi, V. A New Approach to the Solution of Economic Dispatch Using Particle Swarm Optimization with Simulated Annealing. // arXiv preprint arXiv:1307.3014 2013

[12] Park, J.-B.; Lee, K.-S.; Shin, J.-R.; Lee, K.-S. A particle swarm optimization for economic dispatch with nonsmooth cost functions. // Power Systems, IEEE Transactions on. 20, (2005), pp. 34-42. https://doi.org/10.1109/TPWRS.2004.831275

[13] Puri, V.; Chauhan, Y. K. A Solution to Economic Dispatch Problem Using Augmented lagrangian Particle Swarm Optimization. // International Journal of Emerging Technology and Advanced Engineering. 2, (2012), pp. 511576.

[14] Kim, J.; Kim, C. S.; Geem, Z. W. A Memetic Approach for Improving Minimum Cost of Economic Load Dispatch Problems. // Mathematical Problems in Engineering. Vol. 2014, (2014). https://doi.org/10.1155/2014/906028

[15] Kim, M. J.; Song, H.-Y.; Park, J.-B.; Roh, J.-H.; Lee, S. U.; Son, S.-Y. An Improved Mean-Variance Optimization for Nonconvex Economic Dispatch Problems. // Journal of Electrical Engineering \& Technology. 8, (2013), pp. 80-89. https://doi.org/10.5370/JEET.2013.8.1.080

[16] Güvenç, U.; Sönmez, Y.; Duman, S.; Yörükeren, N. Combined economic and emission dispatch solution using gravitational search algorithm. // Scientia Iranica. 19, (2012), pp. 1754-1762. https://doi.org/10.1016/j.scient.2012.02.030

[17] Ashfaq, A.; Khan A. Z. Optimization of Economic Load Dispatch Problem by Linear Programming Modified Methodology. // in International Conference on Emerging Trends in Engineering and Technology, 2014.

[18] Shaw, B.; Ghoshal, S.; Mukherjee, V.; Ghoshal, S. Solution of economic load dispatch problems by a novel seeker optimization algorithm. // International Journal on Electrical Engineering and Informatics. 3, (2011), pp. 2642. https://doi.org/10.15676/ijeei.2011.3.1.3

[19] Bisen, D.; Dubey, H. M.; Pandit, M.; Panigrahi, B. Solution of large scale economic load dispatch problem using quadratic programming and GAMS: A comparative analysis. // Journal of Information and Computing Science. 7, (2012), pp. 200-211.

[20] Wang, Y.; Cai, Z. A hybrid multi-swarm particle swarm optimization to solve constrained optimization problems. // Frontiers of Computer Science in China. 3, (2009), pp. 3852. https://doi.org/10.1007/s11704-009-0010-x

[21] Kennedy, J. Particle swarm optimization. // Encyclopedia of Machine Learning, Springer. 2010, pp. 760-766.

[22] Storn, R.; Price, K. Differential evolution-a simple and efficient heuristic for global optimization over continuous spaces. // Journal of global optimization. 11, (1997), pp. 341-359. https://doi.org/10.1023/A:1008202821328

[23] Dhillon, J.; Kothari, D. The surrogate worth trade-off approach for multiobjective thermal power dispatch problem. // Electric Power Systems Research. 56, (2000), pp. 103-110. https://doi.org/10.1016/S0378-7796(00)00092-4

\section{Authors' addresses}

Aamir Nawaz, Lecturer

Faculty of Engineering \& Technology, Gomal University,

Dera Ismail Khan-29050, Pakistan

E-mail: aamirnawaz@gu.edu.pk

Ehtasham Mustafa, Lecturer

Faculty of Engineering \& Technology, Gomal University,

Dera Ismail Khan-29050, Pakistan

E-mail: ehtashammustafa@gu.edu.pk

Nasir Saleem, Assistant Professor

Faculty of Engineering \& Technology,

Gomal University,

Dera Ismail Khan-29050, Pakistan

E-mail: nasirsaleem@gu.edu.pk

Dr. Muhammad Irfan Khattak, Associate Professor

Faculty of Engineering \& Technology,

Gomal University,

Dera Ismail Khan-29050, Pakistan

E-mail: dr.irfan@gu.edu.pk

Dr. Muhammad Shafi, Associate Professor

Faculty of Engineering,

University of Science and Technology,

Bannu-28100, Pakistan

E-mail:muhammad.shafi@gmail.com

Abdul Malik, Lecturer

Faculty of Engineering \& Technology,

Gomal University,

Dera Ismail Khan-29050, Pakistan

E-mail: engr.malik87@hotmail.com 